http://economix.fr

Regulation, Institutions and Productivity: New Macroeconomic Evidence From OECD Countries

Document de Travail

Balázs Égert

Working Paper

2017-18 


\title{
REGULATION, INSTITUTIONS AND PRODUCTIVITY: NEW MACROECONOMIC EVIDENCE FROM OECD COUNTRIES
}

\author{
Balázs Égert $*^{1}$
}

\begin{abstract}
Empirical research on the drivers of multi-factor productivity (MFP) is abundant at the firm- and industry level but surprisingly little research has been conducted on the determinants of MFP at the macroeconomic level. In this paper, we seek to understand the drivers of country-level MFP with a special emphasis on product and labour market policies and the quality of institutions. For a panel of OECD countries, we find that anticompetitive product market regulations are associated with lower MFP levels and that higher innovation intensity and greater openness go in tandem with higher MFP. We also find that the impact of product market regulations on MFP may depend on the level of labour market regulations. Better institutions, a more business friendly environment and lower barriers to trade and investment amplify the positive impact of R\&D spending on MFP. Finally, we also show that cross-country MFP variations can be explained to a considerable extent by cross-country variation in labour market regulations, barriers to trade and investment and institutions (including corruption).
\end{abstract}

JEL classification codes: C23, C51, J2, L43, L51, O4

Keywords: multi-factor productivity, trade openness, innovation, product market regulation, labour market regulation, institutions, policy interactions, OECD

* OECD, Economics Department; EconomiX at the University of Paris X-Nanterre; and CESifo. Email: balazs.egert@oecd.org

1 The paper benefited from very helpful comments from Gilbert Cette, Alain de Serres, Peter Gal, Yvan Guillemette, John Haltiwanger, Mikkel Hermansen, Catherine L. Mann, Nick Johnstone, William Roos, Jan Strasky and David Turner. The author is grateful to Arnaud Cerbelaud, Magdalena Kizior, Adam Theising and Isabelle Wanner for excellent research assistance at different stages of this research. The views expressed in the paper are those of the author and do not necessarily reflect the opinions of the OECD or any other institution the author is affiliated with. 


\section{Introduction}

Empirical research on the drivers of multi-factor productivity (MFP) is abundant at the firm level (Bartelsman et al., 2004; Syverson, 2011). Differences in plant-level productivity may be due to distortion in the allocation of capital and labour (Bartelsman et al. 2014). Evidence suggests that these distortions are partly driven by labour and product market regulations and FDI restrictions (Andrews and Cingalo, 2014). Studies at the industry level identify a negative relation between the stringency of product market regulation and MFP (Nicoletti and Scarpetta, 2003) and show that the negative impact transits through the impact of regulation on R\&D (Cette et al., 2013). Labour market regulations are also found to matter for MFP at the sector level (Cette et al., 2014). It is common wisdom that innovation intensity and trade openness boost MFP at the macroeconomic level (Isaksson, 2007). Yet there is surprisingly little empirical evidence on the impact of structural policies and institutions on aggregate MFP.

Against this background, this paper investigates the drivers of aggregate MFP for an unbalanced panel of 34 OECD countries covering about 30 years at annual frequency. In particular, we estimate the impact of product and labour market regulations and the quality of institutions on country-level MFP. We analyse whether policies interact with each other, whether the quality of institutions influences the impact of policies and the extent to which cross-country variation in policies and institutions helps understand the dispersion of MFP across countries.

The rest of the paper is organised as follows. Section 2 provides a discussion on modelling and data issues. Section 3 deals with estimation issues. Section 4 shows some stylised facts. Section 5 report descriptive statistics and preliminary data analysis. Section 6 reports the estimation results. Section 7 provides some concluding remarks.

\section{The determinants of MFP}

This section looks at the potential drivers of MFP, and discusses the channels through which these variables can potentially influence MFP. The section also gives details on data sources and how data are constructed. Throughout the paper, a measure of MFP is used that includes human capital. That is, MFP is obtained as output minus physical capital and labour and not as output minus human and physical capital and labour. This is consistent with typical MFP measures used in firm- and industry-level studies (Gal, 2013). A detailed discussion on measurement issues related to MFP is provided in Égert (2017).

\subsection{The determinants of MFP}

\subsection{The productivity frontier}

Sector- and firm-level studies (Cette et al. 2013a,b; Nicoletti and Scarpetta, 2003; Griffith et al., 2004) typically include the absolute productivity frontier in the estimated equations. The coefficient estimate on the productivity frontier gives the extent of convergence to the frontier. If the coefficient equals 1 , there is perfect convergence in the long-run to the productivity frontier. ${ }^{2}$ If it is smaller than 1 , convergence is only partial. If, on top of the productivity frontier, other variables such as product and labour market regulation are also included into the long-run relationship, convergence can take place to the absolute frontier corrected for regulatory settings in the country considered: regulations can permanently lower the level of the MFP frontier a country converges to in the long run.

2 In practice, many studies use the gap to the frontier. This indeed is tantamount to restricting the coefficient on the frontier to unity. 
Using the absolute productivity frontier at the macroeconomic level is trickier for two reasons. First, at the firm level, productivity is compared for firms belonging to the same sector. At the aggregate level, however, composition effects may play an important role: a country specialised in agriculture may never be able to exhibit MFP levels observed in a highly industrialised country merely by increasing MFP in agriculture. ${ }^{3}$ Second, if the country at the productivity frontier is small, it is unreasonable to expect that large countries would converge to it. In our dataset, Luxembourg and Norway are often found to be at the absolute MFP frontier. To alleviate the second problem, the MFP level of the USA will be used as the MFP frontier in our empirical analysis.

An alternative and more standard approach in terms of cointegration would be to model MFP levels with convergence to a conditional frontier derived from the absolute MFP frontier. In such a setup, one would seek to establish the drivers of MFP levels and convergence would take place towards the estimated, country-specific long-run relationship in an error correction framework. In this sense, this is also convergence, which takes place towards a country-specific (estimated) MFP frontier. This approach is used for instance in Westmore (2013) and Andrews and Westmore (2014). They determine the country-specific productivity frontier - to which convergence takes place through an error correction mechanism - as a cointegrating relationship between observed MFP and product market regulation. However, year fixed effects introduced into the cointegration analysis are akin to the use of an MFP frontier. The frontier given by year fixed effects is more flexible than using a country or group of countries as the MFP frontier since it captures the common trend for all countries in a panel setting that is allowed to change over time. The covariates used in such regressions explain the gap between the common trend and country-specific MFP developments, i.e. by how much countries diverge from this common trend due to the covariates. ${ }^{4}$

\subsection{Innovation intensity}

This paper uses a number of alternative measures for innovation intensity measured by spending on R\&D. Two types of R\&D spending are used: business expenditures on R\&D (BERD) and general (or total) expenditures on R\&D (GERD). Both measures are further decomposed into expenditures financed by industry (GERDPRIV, BERDPRIV) and expenditures financed by the government (GERDPUB, BERDPUB). The source of these series is the OECD's Main Science and Technology Indicators database.

We also use a measure of general expenditures on basic R\&D, capturing fundamental research. Another way of capturing basic research is to look at Nobel Prize winners (Horvath, 2011). We collected data on the Nobel Prize winners for medicine, biology, chemistry and physics from 1985 to 2014. This alleviates problems related to endogeneity between R\&D and MFP. Nobel Prizes are assigned to countries not in terms of nationality of the laureates but as a function of the affiliation at the time of the Nobel Prize. Shared Nobel Prizes are split, if applicable, across countries proportionately to the number of laureates.

This is a modified version of the variable constructed by Horvath (2011). He uses data for four categories of Nobel Prize winners: physics, chemistry, medicine and economics. We take up this idea but construct an indicator excluding economics (as it conveys limited knowledge on technological progress). Our horizon is also different. Horvath (2011) constructs his Nobel Prize measure for 1945 to 1975 . We use data from 1985 to 2014 as the award of the Nobel Prize awards generally lags the discovery and associated R\&D investment by decades.

\footnotetext{
3 In the very long run, convergence can take place through a sectoral shift in the economy.

$4 \quad$ Results are only reported for the second method. Estimations in which the US MFP series is also used as an explanatory variable are not working very well.
} 


\subsection{Trade openness}

Trade openness is usually considered as enhancing technology diffusion and adoption through trade (and foreign direct investment), resulting in a higher MFP level. Trade openness can be calculated as the sum of exports and imports of goods and services over GDP (divided by two). Data used for the calculation are drawn from the World Bank's WDI database. The openness indicator starts in 1960 and runs until 2013 for most countries. For countries of the former soviet bloc (CZE, EST, HUN, POL, SVN, SVK), the series start in the early/mid-1990s.

One potential problem with trade openness is that it tends to be naturally greater for smaller countries and lower for larger countries. For instance, individual federal states within Germany are comparably open to countries similar in size (e.g. Slovakia or the Czech Republic). Nevertheless, Germany as a country is much less open, as federal states trade a lot with each other. One way to account for this size bias is to regress openness on country size, measured for instance by total population. The regression residuals are the part of openness, which cannot be explained by country size. Therefore, they can be considered as a measure of size-adjusted openness. This paper uses such a size-adjusted openness ratio.

The adjusted trade openness measure is derived from a pooled regression for the 34 OECD countries without country and time fixed effects. Openness, expressed in percentage points is regressed on a constant and population (in million inhabitants) for 1960 to 2011. The constant and the coefficient estimate on total population are 38.96 and -0.178 , respectively and statistically significant at the $1 \%$ level. The regression's adjusted R-squared is 0.176. Also, log openness is regressed on a common constant and log total population for the same period. The constant and the coefficient estimate on log total population are 3.96 and -0.250 , respectively and statistically significant at the $1 \%$ level. The regressions adjusted R-squared is 0.405. This implies that country size is indeed negatively correlated to openness but openness can be explained only partially by country size.

\subsection{Product, labour market regulations and tax policies}

Product market regulation could be captured by the OECD's Product Market Regulation (PMR) indicator or the World Bank's Doing Business indicator. The drawback of the PMR indicator is that it is available every five years $\left(1998,2003,2008\right.$ and 2013). ${ }^{5}$ The Doing Business indicators are available at annual frequency. However, they only cover the period from 2002 to 2014.

The OECD's electricity, transport and communications regulation (ETCR) indicator, a subset of the OECD's Product Market Regulation (PMR) indicator, covers a longer period as it starts in 1975 and ends in 2013. It also has annual observations. For these two reasons, this paper uses the ETCR indicator, which measures the degree of product market regulation on a scale of 0 to $6 .^{6}$ Low numbers indicate less regulation, higher numbers refer to more stringent regulation. The rationale for using this indicator is that more stringent regulation would be associated with a lower MFP level. We will also use the two components of ETCR: barriers to entry and public ownership. It should be noted that data are not available for the USA in the 2013 vintage of the ETCR indicator. We therefore use the 2007 vintage for the USA. The value in 2007 is used to replace the missing values from 2008 to 2011 (the estimation period ends in 2011 as MFP series stop in 2011).

\footnotetext{
$5 \quad$ Westmore (2013) and Andrews and Westmore (2014) use the PMR indicator by filling in the gaps between the observations in 1998, 2003, 2008 and 2013 via linear interpolation.

For the full sample of OECD countries, the correlation between the ETCR and PMR indicator, for the years PMR is available, is about 0.8 .
} 
In addition to product market regulation, labour market regulation can also bear an impact on MFP through the direct effects of the allocation of labour resources and the indirect impact on capital reallocation. Therefore, we use three indicators capturing labour market regulation: i.) per capita spending on active labour market policies (ALMP), ii.) the employment protection legislation (EPL) indicator (for permanent contracts), and iii.) the gross unemployment benefit replacement rate. These data series are borrowed from Gal and Theising (2015), who provide details on data sources and definitions.

\subsection{Controls - human capital and the output gap}

Human capital is used as a control variable for at least two reasons. First, human capital is conducive to the creation and adoption of new technologies. Second, in cases where the measure of MFP implicitly includes the contribution of human capital, the inclusion of the control variable will serve to strip the estimates of the resulting measurement error.

A measure of output gap is employed to control for short-term cyclical fluctuations in the annual MFP series. Output gap is obtained as the difference between the level of real GDP and a trend estimated using the HP filter. To alleviate the famous end-point problem, the real GDP series were extended: beyond 2013, OECD projections were used (Table 1).

Table 1. Variable definitions and sources - time-varying variables

\begin{tabular}{|c|c|c|c|}
\hline NAME & DEFINITION & SOURCE & $\begin{array}{l}\text { MAX TIME } \\
\text { COVERAGE }\end{array}$ \\
\hline \multicolumn{4}{|l|}{ Openness } \\
\hline open & $\begin{array}{l}\text { exports and imports of goods and services over GDP divided by two } \\
\text { openness adjusted for country size, obtained as the residual } \\
\text { from a regression of openness on a constant and total population }\end{array}$ & $\begin{array}{l}\text { World Bank WDI } \\
\text { World Bank WDI }\end{array}$ & $\begin{array}{l}1960-2013 \\
1960-2011\end{array}$ \\
\hline \multicolumn{4}{|c|}{ Innovation intensity } \\
\hline $\begin{array}{l}\text { berd } \\
\text { berdpriv } \\
\text { berdpub } \\
\text { gerd } \\
\text { gerdpriv } \\
\text { gerdpub } \\
\text { gerdbasic } \\
\text { nobel }\end{array}$ & \begin{tabular}{|l|} 
business expenditures on R\&D, \% of GDP \\
business expenditures on R\&D, financed by industry, \% of GDP \\
business expenditures on R\&D, financed by government, \% of GDP \\
general expenditures on R\&D, \% of GDP \\
general expenditures on R\&D, financed by industry, \% of GDP \\
general expenditures on R\&D, financed by government, \% of GDP \\
general expenditures on basic R\&D, \% of GDP \\
Nobel prize winners in hard sciences (economics excluded), 1985 and
\end{tabular} & $\begin{array}{l}\text { OECD Main STI indicators } \\
\text { OECD Main STI indicators } \\
\text { OECD Main STI indicators } \\
\text { OECD Main STI indicators } \\
\text { OECD Main STI indicators } \\
\text { OECD Main STI indicators } \\
\text { OECD Main STI indicators } \\
\text { data collected from }\end{array}$ & $\begin{array}{l}1981-2013 \\
1981-2013 \\
1981-2013 \\
1981-2013 \\
1981-2013 \\
1981-2013 \\
1981-2013 \\
1985-2014 \\
\end{array}$ \\
\hline \multicolumn{4}{|c|}{\begin{tabular}{|l|l} 
Product market regulations &
\end{tabular}} \\
\hline $\begin{array}{l}\text { ETCR all } \\
\text { ETCR en } \\
\text { ETCR po }\end{array}$ & $\begin{array}{l}\text { Regulation in Electricity, Transport and Communication (ETCR) } \\
\text { entry barriers in ETCR } \\
\text { public ownership in ETCR }\end{array}$ & $\begin{array}{l}\text { OECD PMR database } \\
\text { OECD PMR database } \\
\text { OECD PMR database }\end{array}$ & $\begin{array}{l}1975-2013 \\
1975-2013 \\
1975-2013\end{array}$ \\
\hline \multicolumn{4}{|c|}{ Labour market regulations } \\
\hline $\begin{array}{l}\text { ALMP } \\
\text { EPL } \\
\text { gross unemployment } \\
\text { benefit replacement rate }\end{array}$ & $\begin{array}{l}\text { per capita spending on active labour market policies } \\
\text { the employment protection legislation }(E P L) \text { indicator } \\
\text { for permanent contracts }\end{array}$ & $\begin{array}{l}\text { OECD ELS statistics } \\
\text { OECD ELS statistics } \\
\text { OECD ELS statistics }\end{array}$ & $\begin{array}{l}1985-2012 \\
1985-2013 \\
1961-2011\end{array}$ \\
\hline \multicolumn{4}{|l|}{ Controls } \\
\hline $\begin{array}{l}\text { hcap } \\
\text { og }\end{array}$ & $\begin{array}{l}\text { human capital, calculated using a Mincer equation } \\
\text { and mean years of schooling } \\
\text { output gap: difference between the level real GDP } \\
\text { and a trend estimated using the HP filter }\end{array}$ & $\begin{array}{l}\text { OECD EO database } \\
\text { OECD EO database }\end{array}$ & $\begin{array}{l}1980-2013 \\
1960-2013\end{array}$ \\
\hline
\end{tabular}

Source: OECD

\subsection{The role of time-invariant variables: regulations and institutions}

There are a number of variables, which do not change or if they do, they change only very slowly over time. Institutions are typically such variables. Some other variables can be observed only infrequently, or 
only few observations are available for them. Such variables are specific indicators of economic regulations. These variables, which are constants from a purely statistical point of view (Table 2), can be used in three different ways: they can serve as threshold variable in threshold regression, they can be interacted with the time-varying variables summarised in Table 1, or they can be used as constants in the regressions, to replace country fixed effects. For such purposes, the country averages of the time varying variables can also be employed. We adopt the latter approach.

Four groups of constants are used in the empirical analysis (Table 2).

The first group relates to product market regulation: the headline PMR indicator and its disaggregated subindices (state control, barriers to entrepreneurship; and barriers to trade and investment). These series are available from 1998 to 2013 at five year intervals. For each country, the average of the available observations is employed.

The second group includes measures capturing the easy of doing business: the cost and time of insolvency procedures and starting a business, drawn from the World Bank's Doing Business database.

The third group includes institutions (rule of law, the quality of the legal system, law enforcement and judicial independence). These data are obtained from the World Bank's Doing Business database. The quality of the legal system, law enforcement and judicial independence are drawn from the Fraser Institute's Economic Freedom of the World database. For each country, the mean of the available observations is calculated and used in the estimations.

Finally, a number of measures of corruption are used. The degree of corruption reflects the quality of overall institutions. Corruption affects MFP via a mis-allocation of public and private resources. Corrupt governments and administrations will pursue rent seeking. This will lead to the introduction of artificial bottle-necks and increased red tape (OECD, 2016). Favouritism and nepotism introduce distortions by reducing the level playing field. Corruption also disincentivises investment in human and physical capital, especially those with a high risk and high return profile, by increasing overall uncertainty and reducing contract enforcement.

Three different variables measuring corruption are used in the paper: i.) the corruption perception index (CPI) of Transparency International from 2015; ii.) the control of corruption sub-indicator of the World Governance Indicators of the World Bank from 1998 to 2002; and iii.) the corruption index developed by Dreher et al. (2007), covering the period from 1991 to 1997. An increase in the CPI and the WGI's control of corruption indicators imply less corruption, while lower values of the Dreher et al. indicator mean less corruption. 
Table 2. Variable definitions and sources - time-invariant variables

\begin{tabular}{|c|c|c|c|}
\hline \multicolumn{2}{|l|}{ NAME } & SOURCE & $\begin{array}{c}\text { AVERAGED } \\
\text { FOR }\end{array}$ \\
\hline \multicolumn{4}{|c|}{ Product market regulation (PMR) indicator } \\
\hline $\begin{array}{l}\text { overall PMR indicator } \\
\text { State control } \\
\text { barriers to entrepreneurship } \\
\text { barriers to trade\&investment }\end{array}$ & & $\begin{array}{l}\text { OECD, Product Market } \\
\text { Regulations database }\end{array}$ & $\begin{array}{c}\text { 1998-2013, } \\
\text { 5-year intervals }\end{array}$ \\
\hline \multicolumn{4}{|l|}{ Business environemnt } \\
\hline $\begin{array}{l}\text { time of insolvency procedures } \\
\text { cost of insolvency procedures } \\
\text { recovery rate - insolvency procedure } \\
\text { time of starting a business } \\
\text { cost of starting a business } \\
\text { time of contract enforcemet } \\
\text { cost of contract enforcement }\end{array}$ & $\begin{array}{l}\text { resolving insolvency, years } \\
\text { resolving insolvency, \% of estate } \\
\text { as cents on the dollar recovered by secured creditors } \\
\text { days } \\
\% \text { of GNI per capita } \\
\text { days } \\
\% \text { of the claim }\end{array}$ & $\begin{array}{l}\text { World Bank WDI } \\
\text { World Bank WDI } \\
\text { World Bank WDI } \\
\text { World Bank WDI }\end{array}$ & $\begin{array}{l}2004-2012 \\
2004-2012 \\
2004-2012 \\
2004-2012\end{array}$ \\
\hline \multicolumn{4}{|l|}{ Institutions } \\
\hline $\begin{array}{l}\text { rule of law } \\
\text { quality of legal system } \\
\text { corruption: corruption percention index } \\
\text { corruption: corruption percention index } \\
\text { corruption: corruption index }\end{array}$ & & \begin{tabular}{|l|} 
World Bank WDI \\
Fraser Institute's Economic \\
Transparency International \\
World Bank World Governance \\
Indicators \\
Dreher et al. (2007)
\end{tabular} & $\begin{array}{c}2004-2012 \\
1980-2012 \\
2015 \\
1998-2002 \\
1991-1997\end{array}$ \\
\hline
\end{tabular}

Source: OECD

\section{Estimation issues}

\subsection{Linear specifications}

Our baseline equation includes the level of MFP as the dependent variable and openness, innovation intensity and product market regulation as regressors:

$$
\text { MFP }_{j, t}=f\left(\text { OPEN }_{j, t}, \text { INNOVATION }_{j, t}, \text { PMR }_{j, t}\right)
$$

Equation (3) implies that the level of MFP depends on the level of openness (adjusted for country size), innovation intensity (measured as business expenditures on R\&D by the private sector) and the level of product market regulation (PMR). PMR is measured using the OECD's time-varying Energy, Transport, Communications Regulation (ETCR) indicator. Two control variables are used: human capital to control for the human capital part in MFP, and the output gap to filter out the business cycle from the independent and dependent variables. Equation (3) always includes country and time fixed effects. As argued earlier, time fixed effects can be used to capture the MFP frontier.

Equation (3) is also augmented by additional variables on labour market regulations (EPL, ALMP and the unemployment benefit replacement rate):

$$
\text { MFP }_{j, t}=f\left(\text { OPEN }_{j, t}, \text { INNOVATION }_{j, t}, \text { PMR }_{j, t}, L M R_{j, t}\right)
$$

Labour market regulations are measured by three indicators drawn from OECD data sources: the Employment Protection Legislation (EPL) indicator (for permanent contracts), the unemployment benefit replacement rate (UBRR) and spending on active labour market policies (ALMP). Higher values of the first two variables indicate more strict regulation. More ambitious ALMP is expected to boost MFP. Higher labour market regulation is expected to be correlated with lower MFP through a worsening in labour reallocation. 


\subsection{Non-linear specifications}

\subsubsection{Smooth and threshold non-linearities}

Policies could have an increasingly or decreasingly negative impact on the capital stock. Such smooth nonlinear effects can be captured by a quadratic function (equation 5).

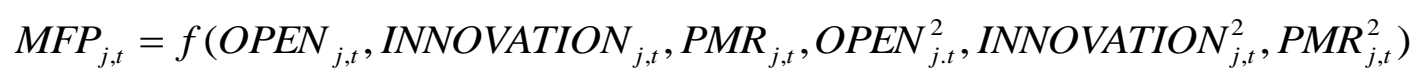

Nonlinear effects can also occur more abruptly when the variable of interest has different coefficients below and above the tipping point of the threshold variable (threshold non-linearity). If the threshold variable is the same variable, this is a classical 'univariate' nonlinear effect. If the threshold variable is another policy variable, the results are comparable to interactions. For instance, the impact of labour market policies could depend on the level of restrictiveness of product market regulation or the other way around (equation 6). The threshold value is determined endogenously through a grid search: A grid search with steps of $1 \%$ of the distribution is carried out to identify the value of the threshold variable that minimises the sum of squared residuals of the estimated two-regime model. The grid search starts at $15 \%$ of the distribution and stops at $85 \%$ to ensure that a sufficient number of observations falls into each regime. There is evidence for nonlinearity if the null hypothesis of $\beta_{1}=\beta_{2}$ can be rejected against the alternative hypothesis of $\beta_{1} \neq \beta_{2}$.

$$
\text { MFP }_{j, t}=\left\{\begin{array}{lll}
\alpha_{1}+\alpha_{2} \text { OPEN }_{j, t}+\alpha_{3} \text { INNOVATION }_{j, t}+\beta_{1} \text { PMR }_{j, t}+\varepsilon_{t} & \text { if } & \text { LMR }<T \\
\alpha_{1}+\alpha_{2} \text { OPEN }_{j, t}+\alpha_{3} \text { INNOVATION }_{j, t}+\beta_{2} \text { PMR }_{j, t}+\varepsilon_{t} & \text { if } & \text { LMR } \geq T
\end{array}\right.
$$

where $\mathrm{T}$ is a given value of $\mathrm{LMR}$.

\subsubsection{Asymmetric effects}

The impact of regulation could be different depending on the direction of the change in regulation, e.g. if regulation is being tightened or relaxed (asymmetric effect). Equation (7) helps test these non-linear effects. Again, we can conclude in favour of an asymmetric effect if the null hypothesis of $\beta_{1}=\beta_{2}$ can be rejected against the alternative hypothesis of $\beta_{1} \neq \beta_{2}$.

$$
\text { MFP }_{j, t}=\left\{\begin{array}{lll}
\alpha_{1}+\alpha_{2} \text { OPEN }_{j, t}+\alpha_{3} \text { INNOVATION }_{j, t}+\beta_{1} \text { PMR }_{j, t}+\varepsilon_{t} & \text { if } & \Delta P M R<0 \\
\alpha_{1}+\alpha_{2} \text { OPEN }_{j, t}+\alpha_{3} \text { INNOVATION }_{j, t}+\beta_{2} \text { PMR }_{j, t}+\varepsilon_{t} & \text { if } & \Delta P M R \geq 0
\end{array}\right.
$$

\subsubsection{Policy interactions: long-term effects}

The impact of one policy could depend on the level of another policy. Threshold regressions allow for two (or more) regimes. Using interactions in the regressions would allow a smoother dependence on the threshold variable. For instance, interacting the time-varying ETCR indicator with a measure of EPL, which is calculated as a country average over the sample period (and demeaned across countries) would tell us by how much the overall coefficient on ETCR would change if a country moves away from the cross-country average (equation 8).

$$
M F P_{j, t}=f\left(\text { OPEN }_{j, t}, \operatorname{INNOVATION}_{j, t}, \operatorname{PMR}_{j, t}, P M R_{j, t} * \overline{L M R_{j}}\right)
$$


This type of analysis can be extended to the time-invariant measures of product market regulation (PMR subcomponents), measures of the ease of doing business and indicators capturing the quality of institutions. Some policies such as institutions change slowly over time and can be observed at high intervals or we only have a small number of observations. These variables cannot be used as determinants of MFP in regressions with country fixed effects (because country fixed effects capture these variables) but could be interacted with the time varying variables. In this case, the interaction term would tell whether the impact of a product or labour market policy would depend on the level of these institutions or other policies (equation 9).

$$
\text { MFP }_{j, t}=f\left(\text { OPEN }_{j, t}, \text { INNOVATION }_{j, t}, \text { PMR }_{j, t}, \text { PMR }_{j, t} * \overline{\text { INSTITUTIONS }_{j}}\right)
$$

\subsubsection{Policy interactions: the impact on the speed of adjustment}

Cross-country variations in policies and institutions could also have an influence on the speed of adjustment in the error correction model. In such cases, the time which is required to reach the long-run equilibrium will depend on the level of policies across countries (the deviation from the cross-country mean). This relationship is estimated based on equation (10) below where $\hat{\varepsilon}_{t-1}$ is the lagged deviation from equilibrium obtained from the first-stage long-term model of our estimation strategy:

$$
\Delta M F P_{j, t}=f\left(\hat{\varepsilon}_{t-1}, \hat{\varepsilon}_{t-1} * \overline{I N S T I T U T I O N S_{j}}\right)
$$

\subsection{Estimation methods}

Given the trending nature of the data (even if country and year fixed effects are accounted for), cointegration techniques are needed to estimate the level relationships linking multi-factor productivity with its long-term drivers. If the variables are not related through a cointegrating vector, the estimated level equations may be spurious.

The long-term coefficients are estimated on the basis of the Dynamic OLS (DOLS) estimator. Over the standard OLS estimator, it has the advantage that it corrects for the possible endogeneity of the regressors and autocorrelation in the residuals by incorporating leads and lags of the regressors in first differences (Stock and Watson, 1993):

$$
Y_{j, t}=\beta_{0}+\sum_{i=1}^{n} \beta_{n} X_{j, i, t}+\sum_{i=1}^{n} \sum_{l=-k_{1}}^{k_{2}} \gamma_{i, l} \Delta X_{j, i, t-l}+\varepsilon_{t}
$$

where $Y_{t}$ is MFP and $\bar{X}$ is the vector of MFP drivers. $\mathrm{j}$ stands for individual countries, $\mathrm{i}$ for the regressors, and k1 and k2 represent respectively lags and leads. Equation (11) can be estimated using country and time fixed effects. In the empirical analysis, one lead and one lag of the covariates will be used. Whether or not the variables of interest are cointegrated can be tested in two ways. First, the residuals obtained from the long-term relationship $\left(\varepsilon_{t}\right)$ can be used to estimate the error correction model in the second stage. There is weak evidence for the presence of cointegration if the error correction term in this second stage is statistically significant and has a negative sign. This implies an error correction mechanism to be in place. A second and more formal test of cointegration is when the estimated residuals from the long-term relationship are tested for the presence of a unit root. The rejection of the null hypothesis of a unit root can be interpreted in favour of cointegration, in the spirit of the Engle and Granger residual-based cointegration approach. This paper uses Kao's residual-based panel cointegration tests (Kao, 1999), which, along equation (11), allow for country-specific intercepts but imposes homogenous coefficients. 


\section{Stylised facts}

Figures 1 and 2 show some stylised facts on MFP and its drivers. Figure 1 suggests a positive correlation between MFP and business spending on R\&D by industry. Figure 1 also shows that there might be a positive connection between MFP and trade openness. Nevertheless, the positive correlation is less obvious than for R\&D. When it comes to regulations and policies, eyeball econometrics indicate that lower values of the OECD's ETCR indicator, capturing product market regulation, tend to go in tandem with higher levels of MFP and that falling ETCR is accompanied with increasing MFP. There also seems to be fairly clear correlation between MFP and spending on ALMP: more spending on ALMP tends to go in tandem with higher MFP levels. The correlation between MFP and EPL is a bit peculiar: the figure looks like depicting hanging grapes. This is because the EPL indicator is changing very little over time but varies greatly across countries. This pattern is validated by the preliminary data analysis hereafter. Finally, Figure 2 suggests a positive relationship between MFP and the quality of institutions: stronger rule of law, a more solid legal system and less corruption are all associated with higher levels of MFP when looking at purely cross-sectional data (period averages).

\section{Figure 1 MFP and its time-varying drivers}
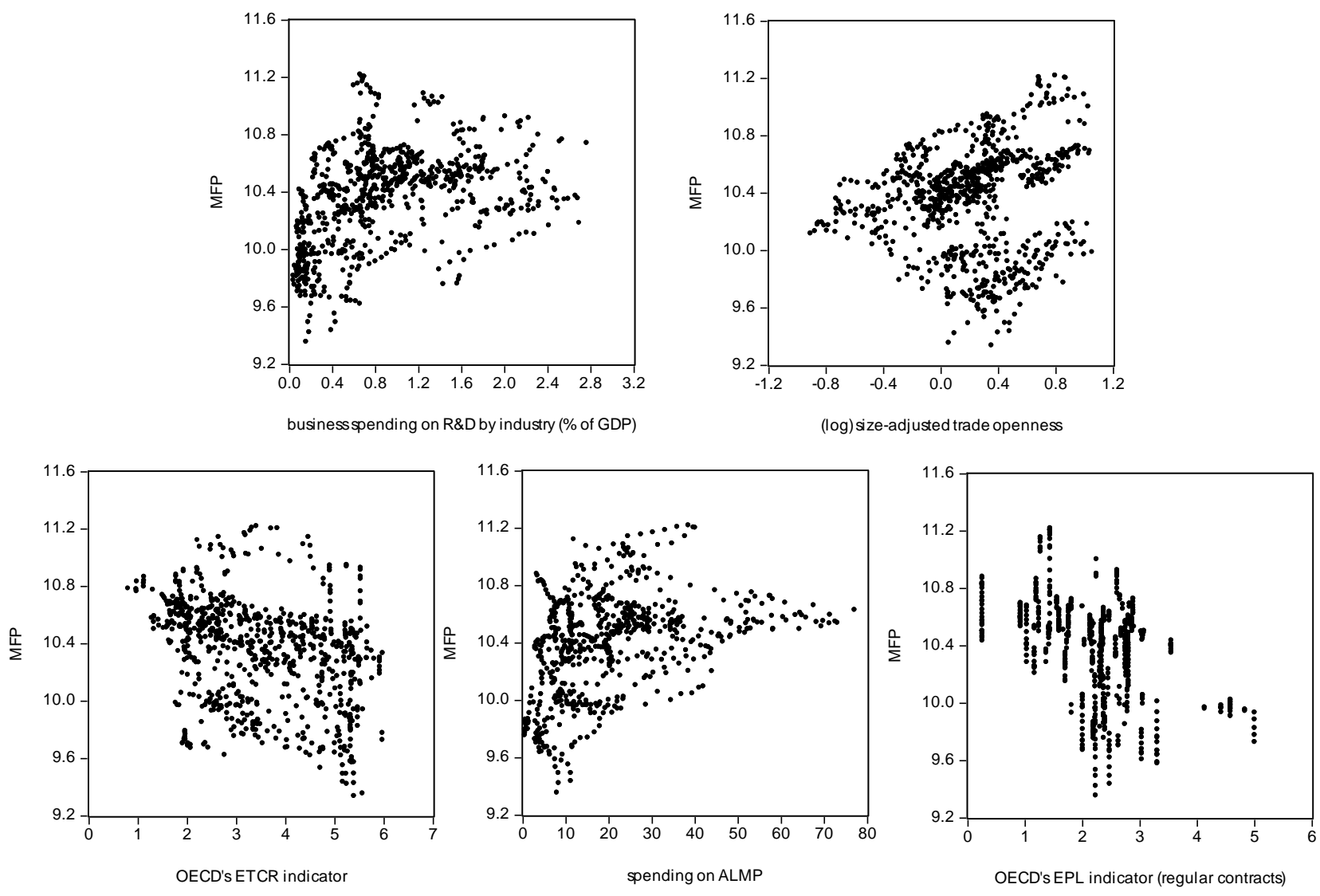

Source: OECD calculations 
Figure 2 MFP and institutions (period averages)
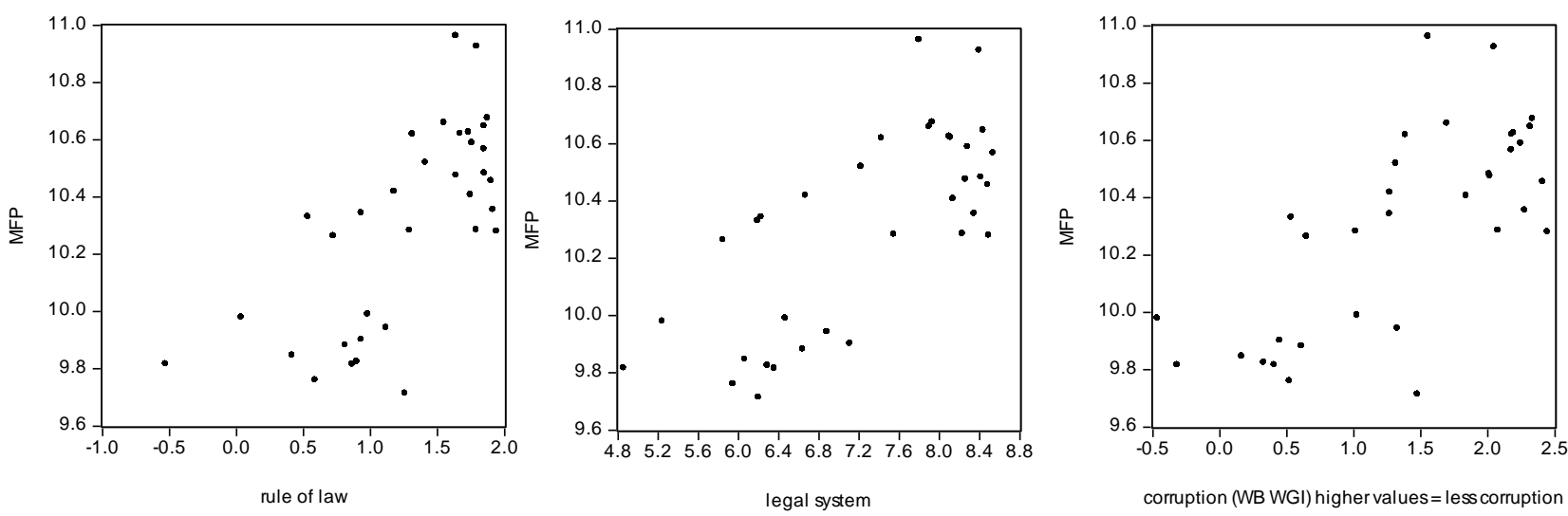

Source: OECD calculations

\section{Descriptive statistics and preliminary data analysis}

Table 3a provides some descriptive statistics of the MFP series and the time-varying policy and control variables ${ }^{7}$. Standard deviations indicate that most variables vary a lot across countries, and much less so over time (once country fixed effects are taken out of the series). For instance, cross-country variation accounts for more than $50 \%$ of total variation for the MFP series and for about two-third for the other variables. A notable exception is the ETCR indicator, which exhibits a substantial average within-country (as opposed to cross-country) variation, even after controlling for common year fixed effects.

Table 4 shows that many explanatory variables are highly correlated with one another. At the same time, no major correlation between the covariates can be detected if both country and year fixed effects are purged from the series. This means that these variables can be used in regressions containing both country and year fixed effects without running into the problem of multi-collinearity. common samples obtained for less policy variables. 
Table 3a Descriptive statistics - time-varying variables

\begin{tabular}{|c|c|c|c|c|c|c|c|c|c|c|c|c|c|}
\hline & & \multicolumn{4}{|c|}{ with CFE \& TFE } & \multicolumn{4}{|c|}{ without CFE } & \multicolumn{4}{|c|}{ without CFE and TFE } \\
\hline & & Min & Max & Mean & Sdev & Min & Max & Mean & Sdev & Min & Max & Mean & Sdev \\
\hline MFP & mfp & 9.34 & 11.22 & 10.35 & 0.36 & -0.49 & 0.36 & 0.00 & 0.13 & -0.28 & 0.28 & 0.00 & 0.08 \\
\hline etcr overall & etcr_new & 0.79 & 6.00 & 3.63 & 1.41 & -2.39 & 2.44 & 0.00 & 1.21 & -1.10 & 1.21 & 0.00 & 0.39 \\
\hline etcr entry barriers & etcr_en & 0.43 & 6.00 & 3.20 & 1.79 & -3.16 & 3.09 & 0.00 & 1.62 & -1.48 & 1.58 & 0.00 & 0.54 \\
\hline etcr public ownership & etcr_po & 0.83 & 6.00 & 3.95 & 1.41 & -2.11 & 3.63 & 0.00 & 0.96 & -1.75 & 2.34 & 0.00 & 0.47 \\
\hline openness size adjusted & open & 7.96 & 185.72 & 39.28 & 23.65 & -36.52 & 60.50 & 0.00 & 9.28 & -28.84 & 48.77 & 0.00 & 6.83 \\
\hline openness, size adjusted & open_adj & -19.88 & 136.05 & 5.53 & 20.29 & -34.30 & 53.85 & 0.00 & 8.62 & -26.29 & 43.49 & 0.00 & 6.20 \\
\hline business exp. on $R \& D$ & berd & 0.01 & 3.76 & 1.07 & 0.74 & -1.45 & 1.16 & 0.00 & 0.31 & -1.23 & 1.27 & 0.00 & 0.26 \\
\hline business exp. on R\&D by industry & berdpriv & 0.02 & 3.07 & 0.89 & 0.64 & -0.84 & 1.10 & 0.00 & 0.26 & -0.90 & 1.12 & 0.00 & 0.22 \\
\hline business exp. on R\&D by government & berdpub & 0.00 & 0.59 & 0.08 & 0.08 & -0.14 & 0.30 & 0.00 & 0.05 & -0.14 & 0.26 & 0.00 & 0.04 \\
\hline general exp. on R\&D & gerd & 0.20 & 4.48 & 1.71 & 0.89 & -1.31 & 1.51 & 0.00 & 0.37 & -1.03 & 1.50 & 0.00 & 0.30 \\
\hline general exp. on R\&D by industry & gerdpriv & 0.03 & 3.14 & 0.94 & 0.65 & -0.90 & 1.09 & 0.00 & 0.26 & -0.90 & 1.12 & 0.00 & 0.22 \\
\hline general exp. on R\&D by government & gerdpub & 0.11 & 1.24 & 0.59 & 0.23 & -0.41 & 0.35 & 0.00 & 0.10 & -0.40 & 0.36 & 0.00 & 0.10 \\
\hline general exp. on basic $R \& D$ & gerdbasic & 0.05 & 0.90 & 0.32 & 0.16 & -0.26 & 0.32 & 0.00 & 0.07 & -0.19 & 0.23 & 0.00 & 0.06 \\
\hline Nobel Prize winners & nobel & 0.00 & 56.34 & 1.31 & 5.88 & -27.89 & 26.44 & 0.00 & 2.97 & -26.67 & 25.23 & 0.00 & 2.88 \\
\hline EPL - permanent contracts & epl & 0.26 & 5.00 & 2.18 & 0.83 & -1.34 & 0.80 & 0.00 & 0.18 & -1.16 & 0.75 & 0.00 & 0.17 \\
\hline spending on active labour market policies & almp & 0.43 & 169.16 & 22.00 & 20.84 & -47.63 & 95.13 & 0.00 & 11.79 & -44.77 & 89.94 & 0.00 & 11.49 \\
\hline unemployment benefit replacement rate & ubrr & 0.35 & 65.21 & 28.18 & 13.28 & -22.00 & 16.19 & 0.00 & 4.93 & -21.71 & 15.35 & 0.00 & 4.72 \\
\hline output gap & oghp & -9.68 & 9.06 & -0.02 & 1.87 & -9.68 & 9.10 & 0.00 & 1.87 & -8.55 & 8.79 & 0.00 & 1.50 \\
\hline human capital & hcap & 1.61 & 3.82 & 3.09 & 0.47 & -0.72 & 0.51 & 0.00 & 0.17 & -0.43 & 0.29 & 0.00 & 0.08 \\
\hline log(human capital) & Ihcap & 0.48 & 1.34 & 1.12 & 0.17 & -0.24 & 0.15 & 0.00 & 0.06 & -0.14 & 0.08 & 0.00 & 0.03 \\
\hline
\end{tabular}

Source: OECD calculations

Note: 'with CFE \& TFE': original series, 'without CFE': residuals from regressions in which the series are regressed on country fixed effects only. 'without CFE \&TFE': residuals from regressions in which the series are regressed on country and time fixed effects only.

Table 3b Descriptive statistics - time-invariant variables

\begin{tabular}{l|cccc} 
& Min & Max & Mean & Sdev \\
\hline PMR \& sub-components & \multicolumn{4}{|c}{} \\
aggregate PMR indicator & 1.18 & 2.80 & 1.73 & 0.35 \\
State control & 1.51 & 3.92 & 2.41 & 0.54 \\
barriers to entrepreneurship & 1.49 & 3.07 & 2.06 & 0.37 \\
barriers to trade and investment & 0.20 & 2.09 & 0.74 & 0.41 \\
\hline Doing business & & & & \\
contract enforcement - cost & 8.31 & 38.63 & 21.46 & 7.81 \\
contract enforcement - time & 216.00 & 1331.67 & 517.34 & 260.00 \\
insolvency - cost & 1.00 & 23.00 & 9.60 & 5.97 \\
insolvency - time & 0.40 & 5.84 & 1.92 & 1.16 \\
insolvency - recovery rate & 18.41 & 92.85 & 65.40 & 21.66 \\
starting a business - cost & 0.05 & 20.69 & 6.80 & 6.42 \\
starting a business - time & 2.71 & 61.08 & 16.83 & 11.68 \\
\hline Institutions & \multicolumn{4}{|c}{} \\
rule of law & -0.53 & 1.94 & 1.27 & 0.60 \\
legal system & 4.86 & 8.54 & 7.27 & 1.07 \\
\hline corruption (Dreher et al.) & -0.90 & 0.26 & -0.22 & 0.31 \\
corruption perception index - TI & 35.00 & 91.00 & 69.88 & 15.61 \\
control of corruption - WB WGI & -0.46 & 2.44 & 1.38 & 0.84
\end{tabular}

Source: OECD calculations 
Table 4 Correlations

\begin{tabular}{|c|c|c|c|c|c|c|c|c|c|c|c|c|c|c|c|c|}
\hline & & etcr_all & etcr_en & etcr_po & open & open_adj & output gap & hcap & berd & berdpriv & berdpub & gerdbasic & nobel & ubrr & almp & epl \\
\hline etcr overall & etcr_all & 1 & 0.85 & 0.77 & -0.31 & -0.16 & -0.07 & -0.40 & -0.10 & 0.05 & -0.40 & -0.04 & 0.51 & 0.18 & -0.08 & 0.33 \\
\hline etcr entry barriers & etcr_en & 0.95 & 1 & 0.52 & -0.28 & -0.13 & -0.05 & -0.28 & -0.22 & -0.10 & -0.37 & -0.03 & 0.48 & 0.09 & 0.10 & 0.20 \\
\hline etcr public ownership & etcr_po & 0.78 & 0.60 & 1 & -0.15 & -0.04 & -0.09 & -0.48 & 0.04 & 0.10 & -0.29 & -0.04 & 0.37 & 0.09 & -0.15 & 0.43 \\
\hline openness & open & -0.02 & -0.17 & 0.34 & 1 & 0.96 & 0.07 & 0.09 & 0.31 & 0.20 & 0.22 & 0.27 & -0.17 & -0.10 & 0.05 & -0.03 \\
\hline openness, size adjusted & open_adj & -0.29 & -0.31 & -0.16 & 0.69 & 1 & 0.06 & -0.01 & 0.26 & 0.20 & 0.05 & 0.25 & 0.05 & -0.07 & 0.06 & 0.00 \\
\hline output gap & output gap & -0.03 & -0.02 & -0.05 & 0.04 & 0.04 & 1 & 0.04 & -0.10 & -0.12 & 0.02 & -0.05 & -0.05 & -0.01 & 0.11 & 0.00 \\
\hline human capital & hcap & -0.49 & -0.42 & -0.49 & -0.10 & 0.15 & 0.02 & 1 & 0.16 & 0.09 & 0.51 & 0.18 & -0.37 & -0.03 & 0.33 & -0.50 \\
\hline business exp. on $R \& D$ & berd & -0.28 & -0.15 & -0.48 & -0.32 & 0.06 & 0.01 & 0.71 & 1 & 0.91 & 0.48 & 0.27 & -0.19 & 0.00 & -0.27 & -0.11 \\
\hline business exp. on $R \& D$ by in & berdpriv & -0.26 & -0.13 & -0.48 & -0.34 & 0.02 & 0.01 & 0.68 & 0.99 & 1 & 0.17 & 0.23 & -0.01 & -0.03 & -0.28 & -0.06 \\
\hline business exp. on R\&D by government & berdpub & -0.06 & 0.06 & -0.26 & -0.30 & 0.17 & 0.02 & 0.34 & 0.40 & 0.29 & 1 & 0.18 & -0.55 & 0.07 & 0.00 & -0.33 \\
\hline general exp. on basic $R \& D$ & gerdba & -0.32 & -0.27 & -0.26 & -0.11 & 0.09 & -0.03 & 0.69 & 0.75 & 0.72 & 0.26 & 1 & -0.03 & -0.07 & 0.07 & -0.02 \\
\hline Nobel Prize winners & nobel & -0.29 & -0.15 & -0.44 & -0.33 & 0.32 & -0.02 & 0.27 & 0.33 & 0.31 & 0.40 & 0.28 & 1 & 0.13 & 0.01 & 0.11 \\
\hline unemployment benefit replacement rate & ubrr & 0.27 & 0.17 & 0.43 & 0.07 & -0.27 & 0.00 & -0.22 & -0.17 & -0.20 & -0.16 & -0.06 & -0.21 & 1 & -0.12 & -0.09 \\
\hline spending on active labour market policies & almp & 0.25 & 0.21 & 0.31 & 0.08 & -0.15 & 0.08 & 0.14 & 0.21 & 0.19 & 0.11 & 0.25 & -0.18 & 0.41 & 1 & -0.09 \\
\hline EPL - permanent contracts & & 0.49 & 0.37 & 0.54 & 0.15 & -0.35 & 0.01 & -0.71 & -0.51 & -0.48 & -0.41 & -0.42 & -0.52 & 0.36 & 0.14 & \\
\hline
\end{tabular}

Source: OECD calculations

Note: Cells in dark grey show correlation coefficients between series purged of country and year fixed effects. White cells report correlation coefficients between the original series (containing both country and year fixed effects).

The Im-Pesaran-Shin test (2003) (IPS) panel unit root test is carried out to investigate the order of integration of the variables used in the empirical analysis. The IPS test allows for heterogeneity across countries in the autoregressive coefficient and the lag length used for individual countries. It tests the null hypothesis of a unit root against the alternative of the absence of a unit root. A model with a trend and a constant and a model with only a constant are used.

The following patterns emerge from the IPS test for the 34 OECD countries for the period of 1985 to 2011 (Table 5). First, the tests show that the majority of the variables are integrated of order 1: they have a stochastic and/or a deterministic trend in levels. Second, a few variables are found to be stationary in levels. That the output gap has no unit root comes without surprise. The other stationary variables are business expenditure on R\&D by the government (berdpub) and spending on ALMP. Third, the IPS test indicates the absence of a unit root for all first- and second-differenced variables.

Table 5. Im-Pesaran-Shin (IPS) panel unit root tests

\begin{tabular}{|c|c|c|c|c|c|c|c|}
\hline & & lev & & 1st & & $2 n d$ & \\
\hline & & c & $c+t$ & c & $c+t$ & c & $c+t$ \\
\hline MFP & $\mathrm{mfp}$ & 0.047 & 0.864 & 0.000 & 0.000 & 0.000 & 0.000 \\
\hline etcr overall & etcr all & 0.457 & 0.819 & 0.000 & 0.000 & 0.000 & 0.000 \\
\hline etcr entry barriers & etcr_en & 0.003 & 0.012 & 0.000 & 0.000 & 0.000 & 0.000 \\
\hline etcr public ownership & etcr_po & 0.437 & 0.071 & 0.000 & 0.000 & 0.000 & 0.000 \\
\hline openness & open & 0.908 & 0.031 & 0.000 & 0.000 & 0.000 & 0.000 \\
\hline openness, size adjusted & open adj & 0.954 & 0.026 & 0.000 & 0.000 & 0.000 & 0.000 \\
\hline output gap & output gap & 0.000 & 0.000 & 0.000 & 0.000 & 0.000 & 0.000 \\
\hline human capital & hcap & 0.000 & 0.000 & 0.000 & 0.000 & 0.000 & 0.000 \\
\hline business exp. on R\&D & berd & 0.671 & 0.175 & 0.000 & 0.000 & 0.000 & 0.000 \\
\hline business exp. on R\&D by industry & berdpriv & 0.376 & 0.087 & 0.000 & 0.000 & 0.000 & 0.000 \\
\hline business exp. on R\&D by government & berdpub & 0.001 & 0.000 & 0.000 & 0.000 & 0.000 & 0.000 \\
\hline general exp. on basic $R \& D$ & gerdbasic & 1.000 & 0.548 & 0.000 & 0.000 & 0.000 & 0.000 \\
\hline Nobel Prize winners & nobel & 1.000 & 1.000 & 0.000 & 0.000 & 0.000 & 0.000 \\
\hline unemployment benefit replacement rate & ubrr & 0.368 & 0.475 & 0.000 & 0.000 & 0.000 & 0.000 \\
\hline spending on active labour market policies & almp & 0.000 & 0.000 & 0.000 & 0.000 & 0.000 & 0.000 \\
\hline EPL - permanent contracts & epl & 0.233 & 0.000 & 0.000 & 0.000 & 0.000 & 0.000 \\
\hline
\end{tabular}

Source: OECD calculations 


\section{Estimation results}

\subsection{Regulations and MFP in linear models}

A strong negative relationship can be pinned down between product market regulation, captured by the overall ETCR indicator (and its sub-components barriers to entry and public ownership) and MFP if only country but no year fixed effects are used. If both country and time fixed effects are included into the regressions, only the coefficient estimate on public ownership is found to be statistically significant, overall ETCR and barriers to entry have large standard errors.

None of the labour market regulation indicators are statistically significant when added one by one to the baseline regression. But ALMP and EPL become statistically significant if used in logs. ${ }^{8}$ The positive sign on ALMP may indicate that more spending on ALMP helps labour reallocation by reducing skill mismatches. The positive sign on EPL is counterintuitive and needs more investigation. One possible explanation is a composition effect if tighter EPL destroys low-skill (low-productivity) jobs and leaves high-skill jobs broadly unaffected ( $\mathrm{Gal}$ and Theising, 2015).

Furthermore, a strong positive link exists between overall $R \& D$ expenditures and MFP. ${ }^{9,10}$ This is not a very surprising finding. Nevertheless, looking at $R \& D$ subcomponents shows that this result is driven by the part of $R \& D$ funded by industry. At the same time, $R \& D$ funded by the government is either statistically not significant or has a negative relationship with MFP. This finding does not change when entering public $R \& D$ with long lags ( 5 years) or when adding R\&D funded by industry and by government in the regressions at the same time. Second, general spending on basic research has a positive relationship to MFP. The economic importance of R\&D on basic research, as opposed to business R\&D is considerably (10 times) larger. Also, and relatedly, the Nobel Prize variable ${ }^{11}$ is found to be statistically significant and with a positive sign: more Nobel Prize winners translate into higher MFP. The effect is not very large though.

Trade openness, adjusted for country size, is positively related to MFP. The coefficient estimates are very stable in magnitude and are statistically significant at the 5\% level in the baseline specifications. Trade openness withstands the probe of a shorter time period but it becomes statistically not significant for a subgroup of advanced OECD countries. ${ }^{12}$ For this subgroup, the coefficient on R\&D almost doubles. This suggests that innovation intensity may be more important for more advanced OECD countries. At the same time, less developed OECD countries may benefit more from technology diffusion and adoption through the trade channel.

These results are based on regressions including a measure of human capital as a control variable. If human capital is excluded from the regression, the coefficient on ALMP is not precisely estimated.

Spending on R\&D can be split into general and business spending on R\&D and into spending on R\&D funded by industry (private sector) and by the government.

The long-term coefficients are estimated using the Dynamic OLS (DOLS) estimator proposed by Stock and Watson (1993).

The idea of this variable is due to Horvath (2011).

Trade openness adjusted for country size is very high and increases very steeply for Luxembourg. We therefore run an MFP regression excluding Luxembourg from the sample (equation (7) in Table $\mathrm{R} 2)$. Estimation results are fairly robust to the exclusion of Luxembourg. 
Our measure of human capital has a positive relation to MFP in estimations including country fixed effects only. However, when time fixed effects are also included, human capital becomes statistically nonsignificant or has a negative sign. Most of the results reported in Tables R1 and R6 hereafter are fairly robust if human capital is not used as a control variable in the regressions. An exception is Table R3 as the positive coefficient on ALMP loses statistical significance. These estimation results are not reported here but are available upon request.

\subsection{MFP and policies: threshold non-linear effects}

Threshold regressions are employed to analyse policy interactions. In such a setting, the impact of one policy on MFP could depend on the level of another policy. Several interesting results emerge from this analysis. First, product and labour market regulations interact with each other. ETCR's negative impact on MFP is at work if EPL is not very restrictive. This finding may also imply for policy makers that implementing product and labour market reforms jointly may bring more benefits than a 'one-sided' reform. Second, the negative impact of ETCR doubles in size for high levels of trade openness: increased external competitiveness pressures may exacerbate the negative ETCR impact through the indirect effect in downstream sectors. Third, ALMP's positive influence on MFP only works if EPL is low: improved labour market matches through higher ALMP spending may only work if it is relatively easy to reallocate labour. Finally, openness and private $R \& D$ spending substitute for each other to some extent. The positive openness effect is smaller if private $R \& D$ spending is high. The positive link between R\&D spending and MFP also weakens at higher levels of openness.

\subsection{MFP and policy interactions: long-term effects}

One way to think about the influence of institutions on policies is through the interaction between timevarying policies (policy outcomes) and (time-invariant) institutions. The interaction term indicates the extent to which institutions amplify or attenuate the impact of time-varying policies on MFP.

Results show that better enforcement of laws implies a more pronounced negative ETCR impact: regulations are more binding if they are applied more strictly. It also appears that more stringent regulation on FDI exacerbates the negative ETCR effect.

The quality of institutions is also found to have an influence on the MFP gains from higher R\&D spending. The estimation results show that a stronger rule of law and better law enforcement amplify the positive effect of R\&D spending. At the same time, more costly and lengthy contract enforcement procedures offset some of the benefits of higher R\&D spending.

Longer and more costly insolvency procedures are found to attenuate the positive impact of R\&D on MFP. Similarly, the benefits of R\&D will be reduced if it takes longer to start a business and if barriers to trade and investment are more binding.

Better educational outcomes, measured by the OECD's PISA scores in mathematics and sciences, magnify the positive effects on MFP of R\&D spending. Better PISA results reflect improved human capital. This can signal the quality of R\&D spending, the ease at which new innovations can be implemented and used by industry but also the ability of a country to adopt foreign technology diffused via foreign trade and investment.

\subsection{The impact of policies and institutions on the speed of adjustment}

Policies and institutions could have an influence on the speed of adjustment towards the long-run equilibrium. The regression results show a general lack of policy interactions on the error correction term: the marginal interaction term is mostly not significant at the conventional 5\% levels (Table R6). There are 
three exemptions. The marginal interaction term on EPL is positive. This suggests that countries with stricter EPL will experience a slower adjustment to the long-term equilibrium. But this also means that any reform that aims a lower EPL will speed up the convergence to the long-run steady state. By contrast, the marginal interaction terms on i.) barriers to trade and investment and ii.) the cost of contract enforcement are negative. As the overall error correction term becomes more negative (larger in absolute terms), this means that countries with higher barriers and higher costs will reduce the gap to the long-run equilibrium at a higher speed. For instance, the impact of bad policies will materialise quicker.

\subsection{Level effects of policies and institutions}

Previous results are based on regressions including country fixed effects. They tell us how changes in policies are related to changes in MFP on average in our panel. But they do not tell why the level of MFP may differ across countries. MFP series have substantial cross-country variation and the cross-country variation is fully captured by country fixed effects. The drivers of cross-country dispersion can be analysed by replacing country fixed effects by variables that have an economic interpretation.

We swap country fixed effects for four variables: the country averages of two labour market indicators (EPL and ALMP), and barriers to trade and investment, and a measure of institutional quality (the rule of law). The new variables capturing cross-country variation in MFP are statistically significant at the standard 5\% level and their sign makes sense economically. More stringent EPL and more restrictive barriers to trade and investment are related to lower MFP levels. At the same time, higher spending on ALMP and better institutions are associated with higher levels of MFP across countries (Table R7).

The results on EPL warrant more discussion. Estimations based on within-country identification (average time effect across OECD countries) pointed out to a positive relation between EPL and MFP (albeit not a robust one). However, allowing for cross-country variation in the data yields a negative coefficient estimate on EPL. Earlier studies (e.g. Andrews and Cingano, 2014) using the cross-country variation in EPL also find a negative relationship between EPL and MFP. When decomposing overall variation into time and cross-country variation, it appears that EPL varies on average much more across countries than over time. This suggests that over time, the composition effect may be at work: tighter EPL destroys lowskill (low-productivity) jobs and leaves high-skill jobs broadly unaffected. Or, businesses could act to counteract tighter EPL by increasing MFP for instance through a more efficient organisation of the production process. Nevertheless, across countries, the differences are larger and these large differences in the degree of labour market regulation may translate into considerably different MFP levels by prohibiting a more efficient allocation of labour (and capital).

The variables used in earlier estimations are reasonably robust to the replacement of country fixed effects: openness and private spending on R\&D are precisely estimated and are positively signed. The ETCR indicator is negatively linked to MFP.

These estimates compare reasonably well with earlier results containing country fixed effects. Pooled regressions account for about $40 \%$ of the variation in the MFP data. Adding country fixed effects improves the goodness of fit remarkably. Our new set of regressions goes more than half way from pooled regressions to those using country fixed effects: the four additional variables add an extra 30 percentage points to the adjusted R-squared.

\subsection{The level effect of corruption}

We now take a look at the level effect of corruption by replacing rule of law by the three measures of corruption (corruption perception index, control of corruption and the corruption index of Dreher et al. (2007). The corruption indicators are all constants and can therefore explain only cross-country differences 
in MFP levels. Empirical evidence shows that a lower (higher) level of corruption is associated with a higher (lower) level of MFP for our sample of OECD countries (Table R8). The coefficient estimates are precisely estimated for all three measures of corruption. This is fairly robust evidence for the harming effects of corruption on cross-country MFP levels. Using the corruption indicators instead of rule of law does not change the results on the other variables.

\section{Conclusions}

For an annual panel of OECD countries covering the last three decade, we found that anticompetitive product market regulations are associated with lower MFP levels and that higher innovation intensity and greater openness result in higher MFP. We also found that the impact of product market regulations on MFP may depend on the level of labour market regulations. Better institutions, a more business friendly environment and lower barriers to trade and investment amplify the positive impact of R\&D spending on MFP. Finally, we also show that cross-country MFP variations can be explained to a considerable extent by cross-country variation in labour market regulations, barriers to trade and investment, and the overall quality of institutions (including corruption).

\section{References}

Andrews, D. and F. Cingano. 2014. "Public policy and resource allocation: evidence from firms in OECD countries." Economic Policy, 29(78): 253-296.

Andrews, D. and C. Criscuolo. 2013. "Knowledge-based capital, innovation and resource allocation." OECD Economics Department Working Paper No. 1046.

Andrews, D. and B. Westmore (2014), "Managerial capital and business R\&D as enablers of productivity convergence", OECD Economics Department Working Papers, No.1137, OECD publishing.

Bartelsman, E., J. Haltiwanger and S. Scarpetta. 2004. "Microeconomic evidence of creative destruction in industrial and developing countries." World Bank Policy Research Working Paper No. 3464.

Bartelsman, E., J. Haltiwanger and S. Scarpetta. 2014. "Cross-country differences in productivity: the role of allocation and selection." American Economic Review, 103(1): 305-334.

Cette, G., J. Lopez and J. Mairesse. 2013. "Upstream product market regulations, ICT, R\&D and productivity." NBER Working Paper No. 19488.

Cette, G., J. Lopez, J. Mairesse. 2014. "Product and labour market regulations, production prices, wages and productivity." NBER Working Paper No. 20563.

Dreher A., C. Kotsogiannis and S. McCorriston. 2007. "Corruption around the world: Evidence from a structural model." Journal of Comparative Economics, 35(3): 443-466

Égert, B. 2017. "Aggregate multi-factor productivity: measurement issues in OECD countries." OECD Economics Department Working Paper (forthcoming)

Gal, P. 2013. "Measuring total factor productivity at the firm level using OECD-ORBIS." OECD Economics Department Working Paper No. 1049.

Gal, P. and A. Theising. 2015. "The macroeconomic impact of policies on labour market outcomes in OECD countries: a reassessment.” OECD Economics Department Working Paper No. 1271.

Horvath, R. 2011. "Research \& development and growth: a Bayesian model averaging analysis." Economic Modelling, 28(6): 2669-2673.

Isaksson, A. 2007. "Determinants of total factor productivity: a literature review." UNIDO, Research and Statistics Branch Staff Working Paper 02/2007. 
Kao, C. (1999), Spurious regression and residual-based tests for cointegration in panel data, Journal of Econometrics, 90(1), 1-44.

Nicoletti, G. and S. Scarpetta. 2003. "Regulation, productivity and growth: OECD evidence." Economic Policy, 18(36): 9-72.

OECD (2016), "Strengthening Public integrity Systems to enhance productivity in the public and private sector", (forthcoming)

Stock, J. and M. Watson. 1993. "A simple estimator of cointegrating vectors in higher order integrated systems.” Econometrica, 61 (4): 783-820.

Westmore, B. (2013), "R\&D, Patenting and Growth: The Role of Public Policy", OECD Economics Department Working Papers", No. 1047. 
DRAFT/ECO/WKP(2016)00

Table R1. Baseline estimation results

\begin{tabular}{|c|c|c|c|c|c|c|c|c|c|c|c|c|c|c|c|c|c|c|c|}
\hline & & (1) & (2) & (3) & (4) & (5) & (6) & (7) & (8) & (9) & (10) & (11) & (12) & (13) & (14) & (15) & (16) & (17) & (18) \\
\hline constant & c & $9.891^{* *}$ & $9.702^{* *}$ & $9.904^{* *}$ & $10.266^{* \star}$ & $10.233^{\star \star}$ & $10.519^{* \star}$ & $10.492^{* *}$ & $10.317^{* \star}$ & $10.817^{* \star}$ & $10.465^{* \star}$ & $10.485^{* *}$ & $10.477^{* *}$ & $10.871^{* \star}$ & $11.39^{* *}$ & $10.504^{* *}$ & $10.2^{\star \star}$ & $10.377^{\star \star}$ & $10.326^{* *}$ \\
\hline etcr overall & etcr_new & $-0.039^{* *}$ & & & -0.005 & & & & & & & & & & & & & & \\
\hline etcr entry barriers & etcr_en & & $-0.024^{* *}$ & & & 0.003 & & & & & & & & & & & & & \\
\hline etcr public ownership & etcr_po & & & $-0.042^{\star \star}$ & & & $-0.026^{\star \star}$ & $-0.027^{\star *}$ & $-0.019^{\star \star}$ & $-0.017^{\star \star}$ & $-0.026^{* \star}$ & $-0.028^{* \star}$ & $-0.024^{\star \star}$ & $-0.02^{\star \star}$ & $-0.016^{*}$ & $-0.022^{* \star}$ & $-0.021^{\star \star}$ & $-0.025^{\star \star}$ & \\
\hline $\log$ (etcr public ownership) & I_etcr_po & & & & & & & & & & & & & & & & & & $-0.053^{* \star}$ \\
\hline openness size adjusted & open_adj & $0.007^{\star \star}$ & $0.007^{* *}$ & $0.008^{\star \star}$ & $0.008^{\star \star}$ & $0.008^{* *}$ & $0.008^{* \star}$ & $0.008^{* *}$ & $0.009^{\star \star}$ & $0.009^{* *}$ & $0.008^{* \star}$ & $0.008^{* \star}$ & $0.008^{* *}$ & $0.008^{* *}$ & $0.011^{\star \star}$ & $0.002^{* \star}$ & $0.009^{* \star}$ & $0.008^{* *}$ & \\
\hline log(openness size adjusted) & I_open_adj & & & & & & & & & & & & & & & & & & $0.197^{* *}$ \\
\hline business exp. on $R \& D$ & & $0.041^{\star \star}$ & $0.038^{\star *}$ & $0.053^{\star \star}$ & $0.031^{\star \star}$ & $0.032^{\star *}$ & $0.038^{* \star}$ & & & & & & & & & & & & \\
\hline business exp. on R\&D by industry & berdpriv & & & & & & & $0.059^{* *}$ & & & & & & & & & $0.072^{* *}$ & & $0.046^{* *}$ \\
\hline business exp. on $R \& D$ by government & berdpub & & & & & & & & $-0.178^{\star *}$ & & & & & & & & $-0.275^{\star \star}$ & & \\
\hline business exp. on R\&D by government $(-5)$ & berdpub5 & & & & & & & & & $-0.186^{* \star}$ & & & & & & & & & \\
\hline general exp. on R\&D & gerd & & & & & & & & & & $0.031^{\star \star}$ & & & & & & & & \\
\hline general exp. on R\&D & gerdp & & & & & & & & & & & $0.054^{* \star}$ & & & & & & $0.065^{* *}$ & \\
\hline general exp. on $R \& D$ by government $(-5)$ & gerdpub5 & & & & & & & & & & & & & -0.01 & & & & & \\
\hline general exp. on basic R\&D & gerdbasic & & & & & & & & & & & & & & $0.349^{* *}$ & & & & \\
\hline Nobel Prize winners & nobel_new & & & & & & & & & & & & & & & $0.003^{* *}$ & & & \\
\hline cointegration test, $\mathrm{HO}$ : no cointegration ( $\mathrm{p}-\mathrm{ve}$ & & 0.012 & 0.010 & 0. & 0.012 & 0.01 & 0.0 & 0.001 & 0.000 & 0.001 & 0.0 & 0.001 & 0.004 & 0.001 & 0.004 & 0.018 & 0.000 & 0.000 & 0.004 \\
\hline error correction term & & $-0.033^{* *}$ & $-0.033^{* *}$ & $-0.029^{* \star}$ & $-0.045^{* \star}$ & $-0.044^{* *}$ & $-0.043^{* *}$ & $-0.043^{* *}$ & $-0.043^{* *}$ & $-0.062^{* *}$ & $-0.042^{* *}$ & $-0.044^{* *}$ & $-0.043^{* *}$ & $-0.067^{* *}$ & $-0.064^{* *}$ & $-0.046^{* x}$ & $-0.045^{* *}$ & $-0.044^{* *}$ & $-0.048^{*}$ \\
\hline adjusted R-squared & & 0.951 & 0.95 & 0.952 & 0.957 & 0.957 & 0.958 & 0.959 & 0.959 & 0.968 & 0.958 & 0.959 & 0.958 & 0.97 & 0.98 & 0.966 & 0.961 & 0.959 & 0.952 \\
\hline No. of observatior & & 756 & 756 & 756 & 756 & 756 & 756 & 755 & 752 & 604 & 758 & 739 & 741 & 604 & 441 & 725 & 752 & 739 & 755 \\
\hline No. of countries & & 34 & 34 & 34 & 34 & 34 & 34 & 34 & 34 & 33 & 34 & 34 & 34 & 3 & 27 & 34 & 34 & 34 & 34 \\
\hline ed effects & & YES & YES & YES & YES & YES & YES & YES & YES & YES & YES & YES & YES & YES & YES & YES & YES & YES & YES \\
\hline time fixed effects & & NO & NO & NO & YES & YES & YES & YES & YES & YES & YES & YES & YES & YES & YES & YES & YES & YES & YES \\
\hline
\end{tabular}

Note: * and ${ }^{* *}$ denote statistical significance at the $10 \%$ and $5 \%$ levels, based on robust standard errors. All regressions include output gap and log(human capital) as a control. 
Table R2. Robustness checks: alternative time and country coverage

\begin{tabular}{|c|c|c|c|c|c|c|c|c|}
\hline & \multirow{2}{*}{\begin{tabular}{|c}
$1980-2006$ \\
$(1)$
\end{tabular}} & \multirow{2}{*}{$\begin{array}{c}1990-2006 \\
\text { (2) }\end{array}$} & \multirow{2}{*}{$\begin{array}{c}1990-2011 \\
\text { (3) }\end{array}$} & \multicolumn{4}{|c|}{ alternative country coverage } \\
\hline & & & & & (4) & (5) & (6) & (7) \\
\hline constant & $\mathrm{c}$ & $10.291^{\star \star}$ & $11.01^{\star \star}$ & $10.954^{\star \star}$ & $10.544^{\star \star}$ & $10.643^{\star \star}$ & $11.198^{\star \star}$ & $10.44^{\star \star}$ \\
\hline etcr public ownership & etcr_po & $-0.025^{\star *}$ & -0.01 & $-0.019^{* *}$ & $-0.026^{\star *}$ & $-0.018^{\star *}$ & $-0.042^{\star \star}$ & $-0.024^{\star \star}$ \\
\hline $\begin{array}{l}\text { openness size } \\
\text { adjusted }\end{array}$ & open_adj & $0.009^{* \star}$ & $0.007^{\star \star}$ & $0.007^{\star \star}$ & $0.008^{\star \star}$ & $0.005^{\star \star}$ & -0.0004 & $0.01^{\star \star}$ \\
\hline $\begin{array}{l}\text { business exp. on R\&D } \\
\text { by industry }\end{array}$ & berdpriv & $0.069^{\star \star}$ & 0.01 & 0.009 & $0.058^{* \star}$ & $0.101^{* *}$ & $0.116^{\star \star}$ & $0.048^{\star \star}$ \\
\hline $\begin{array}{l}\text { cointegration test, } \mathrm{HO} \text { : } \\
\text { cointegration ( } \mathrm{p} \text {-value) }\end{array}$ & & 0.003 & 0.001 & 0.001 & 0.002 & 0.017 & 0.130 & 0.001 \\
\hline error correction term & & $-0.034^{\star *}$ & $-0.059^{* *}$ & $-0.064^{* *}$ & $-0.043^{* *}$ & $-0.044^{* *}$ & $-0.039^{\star *}$ & $-0.048^{\star \star}$ \\
\hline adjusted R-squared & & 0.966 & 0.98 & 0.971 & 0.957 & 0.944 & 0.925 & 0.959 \\
\hline No. of observations & & 622 & 483 & 616 & 718 & 636 & 460 & 746 \\
\hline No. of countries & & 33 & 33 & 34 & 31 & 25 & 17 & 33 (no LUX) \\
\hline country fixed effects & & YES & YES & YES & YES & YES & YES & YES \\
\hline time fixed effects & & YES & YES & YES & YES & YES & YES & YES \\
\hline
\end{tabular}

Note: * and ** denote statistical significance at the $10 \%$ and $5 \%$ levels, based on robust standard errors. All regressions include output gap and log(human capital) as a control. 
Table R3. Baseline specifications augmented with labour market regulations

\begin{tabular}{|c|c|c|c|c|c|c|c|}
\hline & & $(1)$ & (2) & (3) & (4) & (5) & (6) \\
\hline constant & C & $11.279^{\star \star}$ & $10.786^{\star \star}$ & $10.896^{\star \star}$ & $11.016^{\star *}$ & $10.744^{* \star}$ & $10.812^{\star *}$ \\
\hline etcr public ownership & etcr_po & $-0.031^{\star *}$ & $-0.02^{* *}$ & $-0.019^{* *}$ & $-0.025^{\star \star}$ & $-0.021^{* *}$ & $-0.02^{\star *}$ \\
\hline openness size adjusted & open_adj & $0.007^{* *}$ & $0.006^{* *}$ & $0.01^{\star *}$ & $0.006^{* *}$ & $0.006^{\star \star}$ & $0.01^{\star *}$ \\
\hline business exp. on R\&D by industry & berdpriv_ & 0.024 & $0.102^{\star *}$ & 0.016 & 0.032 & $0.1^{* *}$ & 0.022 \\
\hline ALMP & almp_ & 4.0E-04 & & & & & \\
\hline unemployment benefit replacement rate & ubrr & & 2.0E-05 & & & & \\
\hline EPL & epl_ & & & 0.026 & & & \\
\hline $\log (A L M P)$ & I_almp_ & & & & $0.033^{\star *}$ & & \\
\hline log(unemployment benefit replacement rate) & I_ubrr & & & & & 0.001 & \\
\hline $\log (E P L)$ & I_epl_ & & & & & & $0.123^{* *}$ \\
\hline \multicolumn{2}{|l|}{ cointegration test, $\mathrm{H} 0$ : no cointegration ( $\mathrm{p}$-value) } & 0.018 & 0.010 & 0.002 & 0.010 & 0.016 & 0.002 \\
\hline \multicolumn{2}{|l|}{ error correction term } & $-0.062^{* *}$ & $-0.046^{* *}$ & $-0.060^{* *}$ & $-0.055^{\star *}$ & $-0.046^{* *}$ & $-0.060^{* *}$ \\
\hline \multicolumn{2}{|l|}{ adjusted R-squared } & 0.969 & 0.948 & 0.966 & 0.969 & 0.949 & 0.966 \\
\hline \multicolumn{2}{|l|}{ No. of observations } & 570 & 629 & 607 & 570 & 629 & 607 \\
\hline \multicolumn{2}{|l|}{ No. of countries } & 32 & 29 & 34 & 32 & 29 & 34 \\
\hline \multicolumn{2}{|l|}{ country fixed effects } & YES & YES & YES & YES & YES & YES \\
\hline \multicolumn{2}{|l|}{ time fixed effects } & YES & YES & YES & YES & YES & YES \\
\hline
\end{tabular}

Note: * and ** denote statistical significance at the $10 \%$ and $5 \%$ levels, based on robust standard errors. All regressions include output gap and log(human capital) as a control. 
Table R4-1. Threshold regressions - policy interactions

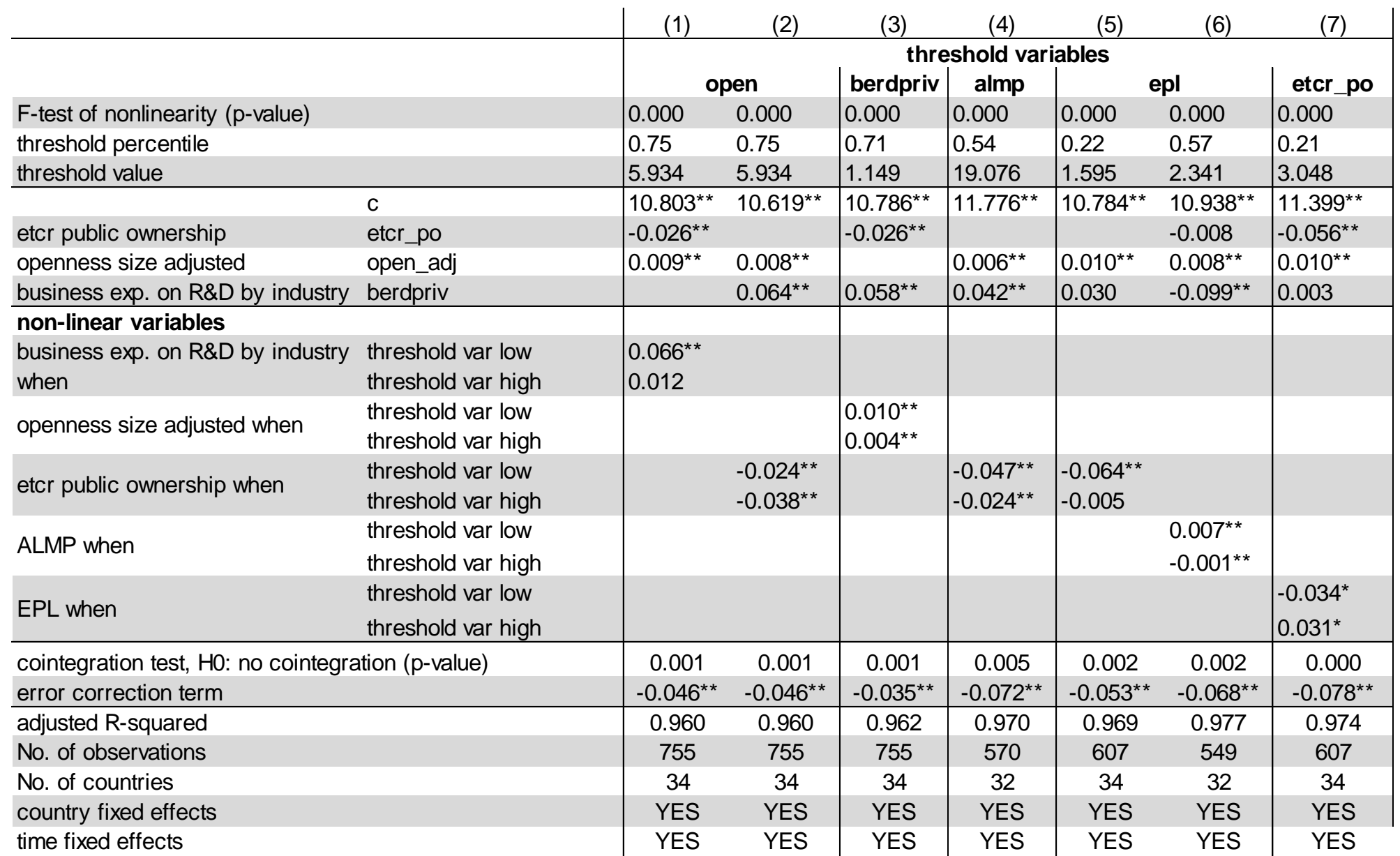

Note: * and ${ }^{* *}$ denote statistical significance at the $10 \%$ and $5 \%$ levels, based on robust standard errors. All regressions include the baseline MFP variables: ETCR public ownership, size-adjusted openness and business expenditures on R\&D by industry. The regressions also include output hap and human capital as control variables. 
Table R4-2. Threshold regressions - policy interactions

\begin{tabular}{|c|c|c|c|c|c|c|c|c|c|}
\hline \multirow[b]{2}{*}{ Threshold variable } & \multicolumn{3}{|c|}{$\begin{array}{l}\text { openness } \\
\text { when }\end{array}$} & \multicolumn{3}{|c|}{$\begin{array}{c}\text { Non-linear variables } \\
\text { business exp. R\&D by } \\
\text { industry } \\
\text { when }\end{array}$} & \multicolumn{3}{|c|}{$\begin{array}{l}\text { ETCR public ownership } \\
\text { when }\end{array}$} \\
\hline & $\begin{array}{l}\text { threshold } \\
\text { value }\end{array}$ & $\begin{array}{c}\text { threshold } \\
\text { var low }\end{array}$ & $\begin{array}{c}\text { threshold } \\
\text { var high }\end{array}$ & $\begin{array}{c}\text { threshold } \\
\text { value }\end{array}$ & $\begin{array}{c}\text { threshold } \\
\text { var low }\end{array}$ & $\begin{array}{c}\text { threshold } \\
\text { var high }\end{array}$ & $\begin{array}{c}\text { threshold } \\
\text { value }\end{array}$ & $\begin{array}{l}\text { threshold } \\
\text { var low }\end{array}$ & $\begin{array}{l}\text { threshold } \\
\text { var high }\end{array}$ \\
\hline \multicolumn{10}{|c|}{ THRESHOLD VARIABLES: TIME-INVARIANT VARIABLES } \\
\hline \multicolumn{10}{|l|}{ Doing business } \\
\hline contract enforcement - cost & 26.80 & 0.001 & $0.012^{* *}$ & 13.67 & $0.15^{\star \star}$ & $-0.062^{\star *}$ & 26.80 & -0.011 & $-0.099^{* *}$ \\
\hline contract enforcement - time & 560.00 & 0.001 & $0.012^{* *}$ & 360.00 & $0.152^{* *}$ & $-0.061^{* *}$ & 567.50 & $-0.02^{* *}$ & $-0.152^{* *}$ \\
\hline insolvency - costs & 15.00 & $0.005^{\star *}$ & $0.015^{\star *}$ & 13.04 & 0.032 & $-0.233^{\star *}$ & 14.50 & $-0.018^{* *}$ & $-0.143^{\star *}$ \\
\hline insolvency - time & 2.29 & $0.005^{\star *}$ & $0.013^{* *}$ & 1.00 & $0.091^{* *}$ & -0.024 & 2.29 & $-0.022^{* *}$ & $-0.14^{* *}$ \\
\hline insolvency - recovery rate & 42.76 & $0.013^{\star *}$ & $0.005^{\star *}$ & & & & 48.89 & $-0.141^{* *}$ & $-0.022^{* *}$ \\
\hline starting a business - cost & 3.72 & $0.012^{* *}$ & $0.003^{* *}$ & 5.46 & $0.052^{* *}$ & $-0.154^{\star *}$ & 3.72 & $-0.062^{\star *}$ & $0.016^{*}$ \\
\hline starting a business - time & 24.88 & $0.005^{\star *}$ & $0.014^{\star *}$ & 24.88 & $0.052^{\star \star}$ & $-0.731^{\star *}$ & 17.50 & $-0.044^{\star *}$ & -0.01 \\
\hline \multicolumn{10}{|l|}{ Institutions } \\
\hline rule of law & 0.98 & $0.015^{\star *}$ & $0.003^{* *}$ & 1.75 & $-0.141^{\star *}$ & $0.077^{* *}$ & 0.93 & $-0.181^{* *}$ & $-0.016^{\star *}$ \\
\hline legal system & 8.10 & $0.01^{* *}$ & -0.001 & 8.40 & $-0.078^{* *}$ & $0.103^{\star *}$ & 6.67 & $-0.17^{\star \star}$ & $-0.026^{\star *}$ \\
\hline
\end{tabular}

Note: * and ** denote statistical significance at the $10 \%$ and $5 \%$ levels, based on robust standard errors 


\begin{tabular}{|c|c|c|c|}
\hline & \multicolumn{3}{|c|}{ time-varying variables } \\
\hline & $\begin{array}{l}\text { ETCR public } \\
\text { ownership }\end{array}$ & $\begin{array}{l}\text { business exp. on } \\
R \& D \text { by industry }\end{array}$ & opennnes \\
\hline \multicolumn{4}{|l|}{$\begin{array}{l}\text { time-invariant variables (interacted with time-varying } \\
\text { variables) } \\
\text { General variables }\end{array}$} \\
\hline business exp. on R\&D by industry (country average) & $0.021 * *$ & 0.014 & $-0.007 * *$ \\
\hline general R\&D basic research (country average) & $0.213 * *$ & 0.135 & $-0.034 * *$ \\
\hline openness (country average) & $-0.001 * *$ & $0.003 *$ & -0.00005 \\
\hline \multicolumn{4}{|l|}{ Policies } \\
\hline ETCR public ownership (country average) & $-0.013 * *$ & $0.102 * *$ & $0.003 * *$ \\
\hline EPL (country average) & $0.019 * *$ & -0.004 & $-0.003 * *$ \\
\hline ALMP (country average) & $0.0004 * *$ & 0.0005 & $-0.0001 * *$ \\
\hline \multicolumn{4}{|l|}{ PMR \& sub-indicators } \\
\hline aggregate indicator & $0.038^{* *}$ & -0.078 & 0.0004 \\
\hline state control & $0.018^{\star *}$ & $0.097^{\star \star}$ & 0.001 \\
\hline barriers to entrepreneurship & $0.041^{* *}$ & -0.047 & 0.0003 \\
\hline barriers to trade and investment & 0.005 & $-0.199^{* *}$ & 0.0001 \\
\hline \multicolumn{4}{|l|}{ Doing business } \\
\hline contract enforcement - cost & $-0.002^{* *}$ & $-0.008^{* *}$ & $0.001^{* *}$ \\
\hline contract enforcement - time & $0.0001^{* *}$ & $-0.0003^{\star *}$ & $1 e-05^{\star \star}$ \\
\hline insolvency - costs & 0.001 & $-0.006^{\star *}$ & $0.0003^{* *}$ \\
\hline insolvency - time & $-0.016^{\star *}$ & $-0.069^{* *}$ & $0.001^{* *}$ \\
\hline insolvency - recovery rate & 0.0004 & 0.002 & 0.000004 \\
\hline starting a business - cost & $0.005^{\star *}$ & $-0.01^{\star *}$ & -0.0002 \\
\hline starting a business - time & $0.001^{* *}$ & $-0.006^{\star *}$ & $-0.0001^{* *}$ \\
\hline \multicolumn{4}{|l|}{ Institutions } \\
\hline rule of law & -0.013 & $0.17^{\star \star}$ & $-0.005^{\star *}$ \\
\hline legal system & $-0.01^{*}$ & $0.077^{\star *}$ & $-0.004^{\star *}$ \\
\hline
\end{tabular}

Note: The coefficients reported are coming from a full specification in line with equation $6 .{ }^{*}$ and ${ }^{* *}$ denote statistical significance at the $10 \%$ and $5 \%$ levels, based on robust standard errors. 
Table R6. The impact of policies on the speed of adjustment, 1985-2013

DRAFT/ECO/WKP(2016)00

\begin{tabular}{l|cc} 
ECM term interacted with & ECM term & $\begin{array}{c}\text { ECM with } \\
\text { interaction }\end{array}$ \\
\hline Product and labour market regulations & & -0.001 \\
ETCR public ownership (country average) & $-0.043^{* *}$ & $0.026^{* *}$ \\
\hline EPL (country average) & $-0.041^{* *}$ & \\
\hline PMR \& sub-indicators & & -0.030 \\
aggregate indicator & $-0.044^{* *}$ & 0.009 \\
$\quad$ state control & $-0.044^{* *}$ & -0.031 \\
$\quad$ barriers to entrepreneurship & $-0.043^{* *}$ & $-0.059^{* *}$ \\
\hline barriers to trade and investment & $-0.047^{* *}$ & \\
\hline Doing business & & $-0.003^{* *}$ \\
contract enforcement - cost & $-0.039^{* *}$ & 0.00001 \\
contract enforcement - time & $-0.043^{* *}$ & 0.001 \\
insolvency - costs & $-0.044^{* *}$ & -0.005 \\
insolvency - time & $-0.044^{* *}$ & 0.0001 \\
insolvency - recovery rate & $-0.044^{* *}$ \\
starting a business - cost & $-0.043^{* *}$ & 0.001 \\
starting a business - time & $-0.047^{* *}$ & $0.001^{*}$ \\
\hline Institutions & & \\
rule of law & $-0.044^{* *}$ & 0.016
\end{tabular}

Note: * and ${ }^{*}$ denote statistical significance at the $10 \%$ and $5 \%$ levels, based on robust standard errors 
Table R7. Replacing country fixed effects by regulations and institutions

\begin{tabular}{|c|c|c|c|c|c|c|}
\hline & (1) & (2) & (3) & (4) & (5) & (6) \\
\hline constant & $9.331^{* *}$ & $9.899^{\star *}$ & $10.492^{* \star}$ & $9.461^{\star *}$ & $11.030^{* *}$ & $10.799^{* *}$ \\
\hline etcr public ownership & -0.002 & $-0.042^{* *}$ & $-0.027^{* *}$ & -0.013 & $-0.026^{* *}$ & $-0.021^{* *}$ \\
\hline openness size adjusted & $0.005^{\star *}$ & $0.008^{\star *}$ & $0.008^{\star *}$ & $0.005^{\star *}$ & $0.002^{* \star}$ & $0.003^{* *}$ \\
\hline business exp. on R\&D by industry & $0.055^{\star *}$ & $0.082^{* *}$ & $0.059^{* *}$ & $0.050^{* *}$ & $0.051^{* *}$ & 0.0180 \\
\hline rule of law - constant & & & & & $0.225^{\star *}$ & $0.351^{* *}$ \\
\hline PMR barriers to trade\&investment - constant & & & & & $-0.173^{\star *}$ & $-0.139 * *$ \\
\hline EPL - country averages & & & & & $-0.207^{\star \star}$ & \\
\hline ALMP - country averages & & & & & $0.006^{* *}$ & \\
\hline EPL & & & & & & $-0.186^{\star \star}$ \\
\hline ALMP & & & & & & $0.004^{* *}$ \\
\hline cointegration test, $\mathrm{H} 0$ : no cointegration ( $p$-value) & 0.001 & 0.001 & 0.001 & 0.001 & 0.001 & 0.006 \\
\hline error correction term & $-0.05^{\star *}$ & $-0.029^{* *}$ & $-0.043^{\star *}$ & $-0.04^{* *}$ & 0.001 & 1.0E-05 \\
\hline adjusted R-squared & 0.410 & 0.953 & 0.959 & 0.411 & 0.694 & 0.732 \\
\hline No. of observations & 755 & 755 & 755 & 755 & 708 & 549 \\
\hline No. of countries & 34 & 34 & 34 & 34 & 32 & 32 \\
\hline country fixed effects & NO & YES & YES & NO & NO & NO \\
\hline time fixed effects & NO & NO & YES & YES & NO & NO \\
\hline
\end{tabular}

Note: * and ${ }^{* *}$ denote statistical significance at the $10 \%$ and $5 \%$ levels, based on robust standard errors 
Table R8. Replacing country fixed effects - the effects of corruption

\begin{tabular}{|c|c|c|c|}
\hline & $(1)$ & $(2)$ & (3) \\
\hline constant & $10.593^{* *}$ & $10.994^{* *}$ & $10.59^{* *}$ \\
\hline product market regulation (ETCR public ownership) & $-0.021^{* *}$ & $-0.021^{* *}$ & -0.005 \\
\hline trade openness (size adjusted) & $0.002^{\star *}$ & $0.001^{*}$ & $0.003^{* *}$ \\
\hline business expenditure on R\&D (\% of GDP) & $0.035^{\star \star}$ & -0.003 & $0.051^{* *}$ \\
\hline output gap & 0.013 & 0.014 & 0.015 \\
\hline log human capital & -0.055 & -0.065 & -0.158 \\
\hline employment protection legislation (EPL) & $-0.183^{\star \star}$ & $-0.195^{\star *}$ & $-0.18^{\star *}$ \\
\hline active labour market policy (ALMP) & $0.004^{* *}$ & $0.005^{\star *}$ & $0.003^{* *}$ \\
\hline $\begin{array}{l}\text { PMR barriess to trade \& investment (cross country) } \\
\text { cross country variables }\end{array}$ & $-0.292^{\star \star}$ & $-0.315^{\star \star}$ & $-0.207^{* *}$ \\
\hline corruption perceptions index (Transp. Inter) & $0.005^{\star \star}$ & & \\
\hline corruption index & & $-0.241^{\star \star}$ & \\
\hline control of corruption (WGI) & & & $0.207^{* *}$ \\
\hline adjusted R-squared & 0.665 & 0.665 & 0.718 \\
\hline No. of observations & 550 & 548 & 550 \\
\hline No. of countries & 32 & 30 & 32 \\
\hline
\end{tabular}

Note: * and ** denote statistical significance at the $10 \%$ and $5 \%$ levels, based on robust standard errors. An increase in the corruption perceptions index and the WGI's control of corruption indicators imply less corruption. By contrast, a lower corruption index of Dreher et al. (2007) means less corruption. 